\title{
Ethical Leadership of Supervisors and Internal Social Capital in a Financial Institution
}

\begin{abstract}
Submitted 12/02/20, $1^{\text {st }}$ revision 08/03/20, $2^{\text {nd }}$ revision 29/03/20, accepted $14 / 04 / 20$
\section{Abstract:}

Myra V. De Leon ${ }^{1}$, Jerwin B. Tubay ${ }^{2}$

Purpose: The aim of this paper is to test empirically if the supervisor's ethical leadership contributes to the creation of internal social capital.

Design/Methodology/Approach: A survey was administered with 158 rank and file employees from 31 Manila branches of a financial institution. Based on factor analysis, reputation of ethical leadership characterized as a moral person and a moral manager emerged as new constructs. Partial least squares structural equation modelling (PLS-SEM) was used.
\end{abstract}

Findings: Findings show that supervisor characterized as being a moral person results to higher willingness of employees to share information and resources in their personal dyadic relationships with supervisor and among employees (structural dimension); increase in employee trust in the long-run fairness of their relationship with the organization and coemployees (relational dimension); and intensification of employees' identification with the firm (cognitive dimension). An ethical supervisor characterized as a moral manager significantly influences the cognitive and structural dimensions of internal social capital.

Practical Implications: The results can give practitioners an idea of the ethical leadership traits observed by rank and file employees. This can have implications for human resource management, particularly superior-subordinate matching and for the process of socialization. In a company and economy that is constantly seeking change-makers and role models, empirical contributions are significant. This study is relevant in proposing strategies that can help management in the creation of social capital as well as contribute to social capital literature and field of business ethics.

Originality/Value: The paper contributes to the existing literature by using financial institutions' employees and in Philippine setting. Previous studies had tested ethical leadership as a whole but this time, the researchers deductively used characteristics of an ethical leader as a moral person and a moral leader.

Keywords: Ethical leadership, capital, moral person and manager.

JEL codes: G20, J24, L29,

Paper type: Research article.

\footnotetext{
${ }^{1}$ Corresponding author, PhD candidate in Business, Decision Sciences and Innovation, De La Salle University-Manila, myra.deleon@dlsu.edu.ph

${ }^{2}$ Assistant Professor, Department of Accountancy, De La Salle University-Manila, jerwin.tubay@dlsu.edu.ph
} 


\section{Introduction}

Social capital within the organization represents the nature of social relations, understood based on the degree of sharing the information, mutual trust and joint goal orientation (Leana and Pil, 2006; Leana and Buren, 1999; Nahapiet and Ghoshal, 1998). Findings of current studies supported the beneficial impact of social capital in organisations (Andrews, 2010; Collins and Smith, 2006; Leana and Pil, 2006; Tsai and Ghoshal, 1998). However, how social capital can be developed require more studies (Adler and Kwon, 2002; Bolino, Turnley and Bloodgood, 2002; Pastoriza, Ariño and Ricart, 2008). Numerous researchers suggest to use deductive theory-testing strategies, beyond quantitative and qualitative approaches (Edelman, Bresnen, Newell, Scarbrough, and Swan, 2004; Pastoriza, Ariño and Ricart, 2009).

This study explored the ethical leadership factors that can influence the internal social capital in a financial institution setting. Specifically, it focused on the contsructs of an ethical leader as a moral person and moral leader and its association with the internal social capital dimensions in a financial institution.

\section{Literature Review}

Ethical leadership as defined by Brown, Treviño, and Harrison (2005) is "the demonstration of normatively appropriate conduct through personal actions and interpersonal relationships, and the promotion of such conduct to followers through two-way communication, reinforcement, and decision-making'. In accordance with the Treviño, Brown and Hartman studies $(2003 ; 2007)$, this concept indicates two aspects of an ethical leader namely a moral person and a moral leader. A moral individual is viewed as a honest, trustworthy, rational and conscientious decisionmaker who displays empathy for others and acts ethically in his or her personal and professional life. Who you are, what you do and what you decide encompasses being a moral person (Treviño, Hartman, and Brown, 2000). On the other side, the moral leader is a strategic attempt of the supervisor to affect the ethical behavior of the subordinates. Constructive initiatives may involve promoting a message about integrity and morals, deliberately modeling ethical action, implementing a compensation program to keep workers responsible for ethical actions, and disciplining any that may not obey expectations (Brown et al., 2005; Treviño et al., 2003; Suryanto and Thalassinos, 2017; Suryanto et al., 2017; Pasaman, 2017).

Internal social capital is the character that ties among members of the organization (Leana and Pil, 2006). Nahapiet and Ghoshal (1998) and Leana and Pil (2006) suggest that internal social capital is the product of three-dimensional interrelations namely structural, cognitive, and relational. The structural dimension of internal social capital represents the degree to which individuals in an organisation become integrated and have access to the intellectual property of others (Nahapiet and Ghoshal, 1998), i.e., with whom and how much they exchange knowledge and services (Moran, 2005). The relational dimension of internal social capital relates to 
the existence and consistency of the linkages between workers (Nahapiet and Ghoshal, 1998). This aspect represents the degree to which connections, interpreted as a tradition of contact, are marked by confidence, reciprocity and emotional strength (Bolino et al., 2002; Moran, 2005). The cognitive aspect of internal social resources involves the degree to which workers hold a shared understanding of the goals of the organization (Moran, 2005; Ismail et al., 2019; Hormati et al., 2017).

Ethical leadership of managers is associated with a stronger desire of workers to exchange knowledge and expertise not just in their specific dyadic relationships with the supervisor, but also with the rest of the company (structural dimension of internal social capital) according to the findings of Pastoriza and Ariño (2013). Employees may feel obligated to act with respect to their immediate supervisor's trusts and is supposed to rely more on teamwork than on rivalry between their peers. (De Hoogh and Den Artog, 2008).

Ethical leadership enhances employee confidence in the long-term integrity of his/ her interaction with the company such as trust to the employer and in the authority of the institution (relational dimension of internal social capital) based on the study by Pastoriza and Ariño (2013). Lewicki and Bunker (1996) concluded that understanding of trustworthy conduct between two people plays an significant role in establishing confidence in the organization.

An ethical leader that expresses empathy about the well- workers will develop their connection with the organization because they feel that the company trusts and supports them (cognitive aspect of internal social capital) as revealed in the study of Pastoriza and Ariño (2013). Findings of Davis and Rothstein (2006) and Walumbwa, Mayer, Wang, Wang, Workman and Cristensen (2011) indicate that the reputation of the supervisor and the manifestation of employee engagement are directly related to the identification of workers with the company as they believe that the institution trusts and supports them.

\section{Methodology}

The research design primarily used the survey method, featuring the established questions from Pastoriza and Ariño (2013). The Likert scales used ranged from 1 (strongly disagree) to 5 (strongly agree). As a tool for analysis, SPSS was used to perform descriptive statistics, reliability analysis, and factor analysis. To test the hypotheses via path analysis, partial least squares structural equation modeling (PLS-SEM) was performed in SmartPLS.

The sample size complied with the recommendation of Hair, Hult, Ringle and Sarstedt (2014). With the maximum number of arrows pointing at a construct, setting the significance level to 0.05 , a statistical power of $80 \%$ and a minimum R2 of .10 , the recommended minimum sample size is 157 . This study was able to gather 158 respondents, which is above the recommended minimum. Pre-test among 30 
employees was conducted. Cronbach's alpha values for ethical leadership, structural dimension of social capital (SC), relational dimension and cognitive dimension are $0.920,0.774,0.815$ and 0.832 respectively. All values have met the acceptable value which is a $>0.60$ according to (Lowry and Gaskin, 2014).

\section{Results}

The profile of the 158 respondents is presented in Table 1.

Table 1. Profile of Respondents

\begin{tabular}{|l|l|l|}
\hline Characteristic & Frequency & \% \\
\hline Gender & & \\
\hline Male & 50 & 31.6 \\
\hline Female & 108 & 68.4 \\
\hline Age & & \\
\hline $22-37$ & 132 & 83.4 \\
\hline $38-53$ & 22 & 13.9 \\
\hline 54 and above & 4 & 14.1 \\
\hline Educational Attainment & & \\
\hline Bachelor's Degree (BD) & 142 & 89.9 \\
\hline Graduate Studies (GS) & 16 & 10.1 \\
\hline Years of Service & & \\
\hline 6 months -5 years & 51 & 32.3 \\
\hline $6-10$ years & 54 & 34.2 \\
\hline $11-15$ years & 40 & 25.2 \\
\hline $16-20$ years & 6 & 3.8 \\
\hline 31 years and above & 7 & 4.5 \\
\hline Source: Own study & & \\
\hline
\end{tabular}

Source: Own study.

The results of Shapiro-Wilk normality test revealed that the variables had significance value below 0.05 . None of the variables were found to be approximately normally distributed: ethical leadership $(\mathrm{W}=.936, \mathrm{p}<.05)$, structural dimension $\mathrm{SC}$ $(\mathrm{W}=.914, \mathrm{p}<.05)$, relational dimension $\mathrm{SC}(\mathrm{W}=.924, \mathrm{p}<.05)$ and cognitive dimension SC $(\mathrm{W}=.945, \mathrm{p}<.05)$.

Factor analysis was used to construct the new factors of ethical leadership affecting employees' internal social capital. Bartlett's test of sphericity and the Kaiser-MeyerOlkin measure of sampling adequacy are both tests that can be used to determine the factoriability of the matrix as a whole. The results value of Bartlett's test of sphericity is significant $(\mathrm{p}=0.000)$ as shown in Table 2 . In addition, the KaiserMeyer-Olkin measure is 0.848 which is greater than 0.6. It is suggested that if the Bartlett's test of sphericity is significant, and if the Kaiser-Meyer-Olkin measure is greater than 0.6, then factorability is assumed (Coakes and Ong, 2011). Based on the results, it is appropriate to proceed with Factor Analysis to examine new factors of ethical leadership affecting internal social capital among the employees. 
Table 2. KMO and Bartlett's Test

\begin{tabular}{|l|l|l|}
\hline \multicolumn{2}{|l|}{ Kaiser-Meyer-Olkin Measure of Sampling Adequacy. } & .848 \\
\hline \multirow{3}{*}{$\begin{array}{l}\text { Bartlett's Test } \\
\text { of Sphericity }\end{array}$} & Approx. Chi-Square & 1.150 .054 \\
\cline { 2 - 3 } & df & 45 \\
\cline { 2 - 3 } & Sig. & .000 \\
\hline
\end{tabular}

Source: Own calculations.

The assumption of independent sampling was met. The assumptions of normality, linear relationships between pairs of variables, and the variables' being correlated at a moderate level were checked. After rotation, two factors were extracted with Eigenvalues greater than 1. The first factor accounted for $58.978 \%$ of the variance and the second factor accounted for $11.207 \%$. When two factors were extracted, then $70.185 \%$ of the variance would be explained. Table 3 displays the items and factor loadings for the rotated factors, with loadings less than .40 omitted to improve clarity.

Table 3. Factor Loadings from Principal Axis Factor Analysis with Varimax Rotation for a Two-Factor Solution for Ethical Leadership Questions $(N=10)$

\begin{tabular}{|l|c|c|c|}
\hline \multirow{2}{*}{ Item } & \multicolumn{2}{|l|}{ Factor Loading } & \multirow{2}{*}{ Communality } \\
\cline { 2 - 3 } & $\mathbf{1}$ & $\mathbf{2}$ & \\
\hline $\begin{array}{l}\text { My supervisor defines success not just by results } \\
\text { but also the way that they are obtained. }\end{array}$ & 0.868 & & 0.758 \\
\hline $\begin{array}{l}\text { My supervisor, when making decisions, asks "what } \\
\text { is the right thing to do?" }\end{array}$ & 0.715 & & 0.633 \\
\hline My supervisor makes fair and balanced decisions. & 0.713 & & 0.744 \\
\hline My supervisor can be trusted. & 0.680 & & 0.695 \\
\hline $\begin{array}{l}\text { My supervisor has the best interests of employees } \\
\text { in mind. }\end{array}$ & 0.677 & & 0.724 \\
\hline $\begin{array}{l}\text { My supervisor listens to what employees have to } \\
\text { say. }\end{array}$ & 0.596 & & 0.671 \\
\hline $\begin{array}{l}\text { My supervisor discusses business ethics or values } \\
\text { with employees. }\end{array}$ & & 0.877 & 0.718 \\
\hline $\begin{array}{l}\text { My supervisor sets an example of how to do things } \\
\text { the right way in terms of ethics. }\end{array}$ & & 0.744 & 0.759 \\
\hline $\begin{array}{l}\text { My supervisor conducts his/her personal life in an } \\
\text { ethical manner. }\end{array}$ & & 0.601 & 0.567 \\
\hline $\begin{array}{l}\text { My supervisor disciplines employees who violate } \\
\text { ethical standards. }\end{array}$ & & 0.445 & 0.456 \\
\hline Eigenvalues & 5.898 & 1.121 & \\
\hline Percentage of variance & 58.978 & 11.207 & \\
\hline Cumulative Percentage & 58.978 & 70.185 & \\
\hline
\end{tabular}

Note: Loadings <.40 are omitted.

Source: Own calculations. 
The first factor, which seems to index the traits of a moral person had strong loadings on the first six items. "My supervisor defines success not just by results but also the way that they are obtained" had its highest loading from the first factor. The second factor, which seemed to index traits a moral manager, had high loadings on the next four items in Table 3. "My supervisor discusses business ethics or values with employees" had its highest loading from the second factor. The two emerged variables in ethical leadership, moral person and moral leader were used as independent variables in PLS analysis.

According to Anderson and Gerbing (1988), PLS analysis includes two steps: measurement model analysis and structural model analysis. The value of the loading factor of the model's variables was initially investigated by running the PLS algorithm function. The results of the model tests are described in Table 4.

Individual item reliability was assessed by examining the factor loadings of all variables with their respective constructs. Results in Table 4 show that all variables met the minimal value of 0.70 (Hair et al., 2014). As to the final measurement of the model's reliability which is the composite reliability, the result showed that all constructs met the requirement of 0.70 (Chin,1998; Fornell and Larcker,1981).

Table 4. Measurement Model Results

\begin{tabular}{|c|c|c|c|c|}
\hline Construct & Item & Loadings & $\mathbf{C R}$ & AVE \\
\hline \multirow[t]{6}{*}{ Moral Person (MP) } & MP1 & 0.859 & \multirow[t]{6}{*}{0.932} & \multirow[t]{6}{*}{0.697} \\
\hline & MP2 & 0.761 & & \\
\hline & MP3 & 0.889 & & \\
\hline & MP4 & 0.843 & & \\
\hline & MP5 & 0.852 & & \\
\hline & MP6 & 0.800 & & \\
\hline \multirow[t]{4}{*}{ Moral Leader (ML) } & ML1 & 0.817 & \multirow[t]{4}{*}{0.883} & \multirow[t]{4}{*}{0.655} \\
\hline & ML2 & 0.862 & & \\
\hline & ML3 & 0.803 & & \\
\hline & ML4 & 0.752 & & \\
\hline \multirow[t]{3}{*}{ Structural Dimension (SD) SC } & SD1 & 0.913 & \multirow[t]{3}{*}{0.902} & \multirow[t]{3}{*}{0.754} \\
\hline & SD2 & 0.878 & & \\
\hline & SD3 & 0.811 & & \\
\hline \multirow[t]{3}{*}{ Relational Dimension (RD) SC } & RD1 & 0.892 & \multirow[t]{3}{*}{0.930} & \multirow[t]{3}{*}{0.816} \\
\hline & RD2 & 0.895 & & \\
\hline & RD3 & 0.923 & & \\
\hline \multirow[t]{4}{*}{ Cognitive Dimension (CD) SC } & $\mathrm{CD} 2$ & 0.752 & \multirow[t]{4}{*}{0.869} & \multirow[t]{4}{*}{0.624} \\
\hline & CD4 & 0.763 & & \\
\hline & CD5 & 0.815 & & \\
\hline & CD6 & 0.828 & & \\
\hline
\end{tabular}

Source: Own calculations.

Another measurement performed is the convergent validity which refers to the degree of agreement of the same concept (Wang and Yang, 2016) and examined 
based on the values of average variance extracted (AVE). As shown in Table 4, the AVE for all constructs was above 0.5, which met the requirement (Fornell and Larcker, 1981). Hence, there is a good convergent validity for the scales.

Discriminant validity was also checked by measuring the variance shared between the construct and other constructs (Chin, 1998; Fornell and Larcker, 1981). As seen in Table 5, all square roots of AVE were higher than their respective correlation coefficients with latent variables. Hence, the Fornell-Kracker criterion is satisfied by the model.

Table 5. Fornell-Larcker Criterion

\begin{tabular}{|l|l|l|l|l|l|}
\hline $\begin{array}{l}\text { Latent } \\
\text { Variables }\end{array}$ & $\begin{array}{l}\text { Cognitive } \\
\text { Dimension SC }\end{array}$ & $\begin{array}{l}\text { Moral } \\
\text { Leader }\end{array}$ & $\begin{array}{l}\text { Moral } \\
\text { Person }\end{array}$ & $\begin{array}{l}\text { Relational } \\
\text { Dimension SC }\end{array}$ & $\begin{array}{l}\text { Structural } \\
\text { Dimension SC }\end{array}$ \\
\hline $\begin{array}{l}\text { Cognitive } \\
\text { Dimension SC }\end{array}$ & $\mathbf{0 . 7 9 0}$ & & & & \\
\hline Moral Leader & 0.497 & $\mathbf{0 . 8 0 9}$ & & & \\
\hline Moral Person & 0.532 & 0.720 & $\mathbf{0 . 8 3 5}$ & & \\
\hline $\begin{array}{l}\text { Relational } \\
\text { Dimension SC }\end{array}$ & 0.552 & 0.485 & 0.548 & $\mathbf{0 . 9 0 3}$ & \\
\hline $\begin{array}{l}\text { Structural } \\
\text { Dimension SC }\end{array}$ & 0.568 & 0.324 & 0.601 & 0.530 & $\mathbf{0 . 8 6 8}$ \\
\hline
\end{tabular}

Source: Own calculations.

There is a strong and positive correlation between moral person, and structural, relational and cognitive dimensions of internal social capital with $0.601,0.548$ and 0.532 respectively. There is a moderate and positive correlation between the moral leader and structural, relational and cognitive dimensions of internal social capital with $0.324,0.458$ and 0.497 respectively. Positive correlations suggest initial support for our hypotheses, and provide evidence that the variables of ethical leadership of supervisors and internal social capital are significantly and positively related (Pastoriza and Ariño, 2013). Subsequent analysis investigates the complexity of these relationships.

A test for multicollinearity was also performed by using the variance inflation factor (VIF). According to Kim, Kim and Wachter (2013), data have a multicollinearity problem when VIFs are greater than 10.00. VIF values of the indicators ranged between 1.477 and 3.686. Hence, there was no significant multicollinearity among indicators. For the model, $37.8 \%$ of the variance of the structural dimension SC, $30.9 \%$ of the variance of the relational dimension SC, and $30.1 \%$ of the variance of the cognitive dimension SC are being explained by the two new factors of ethical managerial behavior.

In analyzing structural models, the model fit should be examined. The threshold to look at are the following: (1) standard root mean square residual (SRMR) to be below 0.10 as suggested by Ringle et al. (2015), (2) normed fit index (NFI) to be 
above 0.90; and (3) root mean squared residual covariance matrix of the outer model residuals (RMS Theta) to be below 0.12 . The values of the saturated model with SRMR of 0.090 , NFI of 0.656 and RMS Theta of 0.211 indicate that the model fit could be improved in succeeding research.

After determining the reliability, validity, multicollinearity and goodness-of-fit indicators of the proposed model, its paths can be analyzed with greater confidence. Structural equation modelling was used to test H1 to H3. Table 6 features path estimates and p-values which was the result of the PLS algorithm and bootstrapping $(\mathrm{J}=10,000)$ procedure performed through SmartPLS 3.0 (Hair et al., 2014; Lowry and Gaskin, 2014). Figure 1 represents the research model with the maximum likelihood parameter estimates and Table 6 the hypotheses results.

Table 6. Hypothesis 1-3 Test Results

\begin{tabular}{|l|l|l|l|l|l|l|}
\hline Paths & $\begin{array}{l}\text { Original } \\
\text { Sample } \\
(\mathrm{O})\end{array}$ & $\begin{array}{l}\text { Sample } \\
\text { Mean } \\
(\mathrm{M})\end{array}$ & $\begin{array}{l}\text { Standard } \\
\text { Deviation } \\
(\mathrm{STDEV})\end{array}$ & $\begin{array}{l}\text { T Statistics } \\
(\mid \mathrm{O} / \\
\text { STDEV })\end{array}$ & $\begin{array}{l}\text { P- } \\
\text { Value } \\
\mathrm{s}\end{array}$ & Decision \\
\hline $\begin{array}{l}\text { H1a: Moral Person } \\
->\text { Structural } \\
\text { Dimension SC }\end{array}$ & 0.763 & 0.750 & 0.108 & 7.076 & 0.000 & Supported \\
\hline $\begin{array}{l}\text { H1b: Moral Leader } \\
->\text { Structural } \\
\text { Dimension SC }\end{array}$ & 0.226 & 0.216 & 0.096 & 2.353 & 0.019 & Supported \\
\hline $\begin{array}{l}\text { H2a: Moral Person } \\
->\text { Relational } \\
\text { Dimension SC }\end{array}$ & 0.413 & 0.426 & 0.075 & 5.500 & 0.000 & Supported \\
\hline $\begin{array}{l}\text { H2b: Moral Leader } \\
->\text { Relational } \\
\text { Dimension SC }\end{array}$ & 0.188 & 0.179 & 0.102 & 1.841 & 0.066 & Rejected \\
\hline $\begin{array}{l}\text { H3a: Moral Person } \\
->\text { Cognitive } \\
\text { Dimension SC }\end{array}$ & 0.363 & 0.359 & 0.093 & 3.881 & 0.000 & Supported \\
\hline $\begin{array}{l}\text { H3b: Moral Leader } \\
\text {-> Cognitive } \\
\text { Dimension SC }\end{array}$ & 0.235 & 0.249 & 0.078 & 3.008 & 0.003 & Supported \\
\hline
\end{tabular}

Source: Own calculations.

\section{Conclusion, Limitations and Avenues for Further Research}

This study was able to identify two dimensions of ethical leadership. Organization's employees recognize an ethical supervisor as a moral person and moral leader. The findings reveal that ethical leadership affect the structural, relational, and cognitive dimensions of internal social capital. First, an ethical leader characterized as a moral person and moral leader promotes structural dimension of social capital. Employees are open to information sharing if the supervisors focus on the best interests of employees and make rational decisions. 
Figure 1. New Model

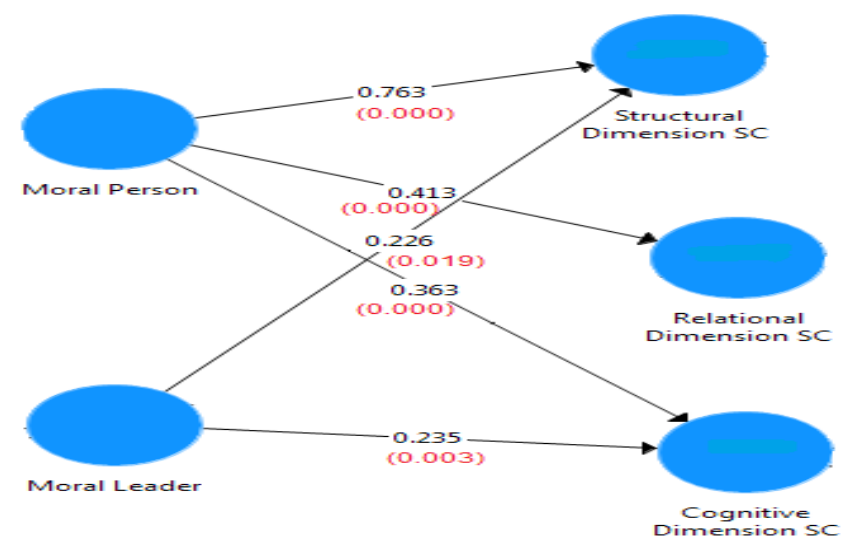

Note: $* * p \leq 0.05$

Source: Own calculations.

Employees trust the supervisors that the information they share will not be used against them. Second, an ethical leader recognized as a moral person generates relational dimension of social capital. If the supervisors behave honestly and principled decision-makers, consequently dyadic trust with employees and trust in the organization will be developed. Employees feel that the organization their rights as employees. Finally, an ethical leader with the characters of a moral person and moral leader creates cognitive dimension of social capital. Supervisors that show honesty and consideration are in a stronger position to have a clear understanding of the goals of the company. Hence, this improves the likelihood that workers can understand and support these goals.

The results of this study can help human resource department, organizational development consultants and supervisors in understanding ethical leadership behaviors that generate internal socail capital. Further, there is certainly a new contribution to knowledge with the development of variables in ethical leadership, albeit in the Philippine context. Empirical results are important in a business and culture that is continuously searching for change-makers and role models.

Future research should investigate and compare the influence of low-, middle- and top-level managers on internal social capital. It would be interesting to study if unethical behavior would not be associated to internal social capital. Finally, a crosscultural analysis should be undertaken.

\section{References:}

Adler, P.S., Borys, B. 1996. Two types of bureaucracy: Enabling and coercive. Administrative Science Quarterly, 41(1), 61-89.

Anderson, J., Gerbing, D. 1988. Structural Equation Modelling in Practice: A Review and Recommended Two-Step Approach. Psychol. Bull., 46, (1-2). 
Andrews, R. 2010. Organizational social capital, structure and performance. Human Relations, 63(5), 583-608.

Bolino, M.C., Turnley, W.H., Bloodgood, J.M. 2002. Citizenship behavior and the creation of social capital in organizations. Academy of Management Review, 27(4), 505-522.

Brown, M.E., Treviño, L.K., Harrison, D.A. 2005. Ethical leadership: A social learning perspective for construct development and testing. Organizational Behavior and Human Decision Processes, 97(2), 117-134.

Chin, W.W. 1998. Issues and Opinion on Structural quation Modeling. MIS Q., 22.

Coakes, J.C., Ong, C. SPSS Version 18.0 for Windows Analysis Without Anguish1st Edition. John Wiley \& Sons, Australia.

Collins, C.J., Smith, K.G. 2006. Knowledge exchange and combination: The role of human resource practices in the performance of high-technology firms. Academy of Management Journal, 49(3), 544-560.

Davis, A., Rothstein, H. 2006. The effects of the perceived behavioral integrity of managers on employee attitudes: A metaanalysis. Journal of Business Ethics, 67(4), 407-441.

De Hoogh, A.H.B., Den Artog, D. 2008. Ethical and despotic leadership, relationships with leader's social responsibility, top management team effectiveness and subordinates' optimism: A multilevel study. The Leadership Quarterly, 19(3), 297-311.

Edelman, L.F., Bresnen, M., Newell, S., Scarbrough, H., Swan, J. 2004. The benefits and pitfalls of social capital: Empirical evidence from two organizations in the United Kingdom. British Journal of Management, 15(1), 59-69.

Fornell, C., Larcker, D.F. 1981. Evaluating Structural Equation Models with Unobservable Variables and Measurement Error, J. Mark. Res., 18 (1), 39.

Hair, J.F.J., Hult, G.T.M., Ringle, C., Sarstedt, M. 2014. A primer on Partial Least Squares Structural Equation Modeling (PLS-SEM) (2nd ed.). Sage Publications, Inc.

Hormati, A., Laduna, R., Mahdi, S.A.R., Kahar, S.H.A. 2017. The Effect of Budgetary Participation on Budgetary Slack Using Budgetary Ethical Compliance. International Journal of Economics and Business Administration, 5(2), 83-99.

Ismail, Y.V., Thauid, A., Hadiwidjojo, D., Indrawati, K.N. 2019. Personality Factors and Servant Leadership on Islamic Microfinance Institution. In: E.I. Thalassinos, (eds.), Developments and Prospects of Business Economics and Finance in Muslim Countries, 1-31, NOVA Science Publishers, Inc., ISBN: 978-1-53615-015-5. https://novapublishers.com/shop/developments-and-prospects-of-businesseconomics-and-finance-in-muslim-countries/.

Kim, Y.H., Kim, D.J., Wachter, K. 2013. A study of mobile user engagement (MoEN): Engagement motivations, perceived value, satisfaction, and continued engagement intention. Decision Support Systems, 56, 361-370.

Leana, C.R., Buren, V. 1999. Organizational social capital and employment practices. Academy of Management Review, 24(3), 538-555.

Leana, C.R., Pil, F.K. 2006. Social capital and organizational performance: Evidence from urban public schools. Organization Science, 17(3), 353-366.

Lewicki, R., Bunker, B.B. 1996. Developing and maintaining trust in work relationships. Thousand Oaks, CA, Sage.

Lowry, P.B., Gaskin, J. 2014. Partial least squares (PLS) structural equation modeling (SEM) for building and testing behavioural causal theory: When to choose it and how to use it. IEEE Transactions on Professional Communication, 57(2), 123-146. https://doi.org/10.1109/TPC.2014.2312452.

Moran, P. 2005. Structural vs. relational embeddedness: Social capital and managerial performance. Strategic Management Journal, 26(12), 1129-1151. 
Nahapiet, J., Ghoshal, S. 1998. Social capital, intellectual capital, and the organizational advantage. Academy of Management Review, 23(2), 242-266.

Pasaman, S. 2017. The Effect of Capital Adequacy Ratio, Net Interest Margin and NonPerforming Loans on Bank Profitability: The Case of Indonesia. International Journal of Economics and Business Administration, 5(3), 70-80.

Pastoriza, D., Ariño, M.A., Ricart, J.E. 2008. Ethical managerial behavior as antecedent of organizational social capital. Journal of Business Ethics, 78(3), 329-341.

Pastoriza, D., Ariño, M.A., Ricart, J.E. 2009. Creating an ethical work context: A pathway to generate social capital in the firm. Journal of Business Ethics, 88(3), 489-777.

Pastoriza, D., Ariño, M.A. 2013. Does the Ethical Leadership of Supervisors Generate Internal Social Capital? Journal of Business Ethics, 118, 1-12.

Treviño, L.K., Brown, M.E., Hartman, L.P. 2003. A qualitative investigation in the executive suite. Human Relations, 56(1), 5-38.

Treviño, L.K., Hartman, L.P., Brown, M. 2007. Moral person and moral manager: How executives develop a reputation for ethical leadership. California Management Review, 42(4), 128-142.

Tsai, W., Ghoshal, S. 1998. Social capital and value creation: The role of intrafirm networks. Academy of Management Journal, 41(4), 464-476.

Suryanto, T., Thalassinos, I.E. 2017. Cultural Ethics and Consequences in Whistle-Blowing among Professional Accountants: An Empirical Analysis. Journal of Applied Economic Sciences, 6(52), 1725-1731.

Suryanto, T., Thalassinos, E.Y., Thalassinos, I.E. 2017. Board Characteristics, Audit Committee and Audit Quality: The Case of Indonesia. International Journal of Economics \& Business Administration 5 (3), 47-57.

Walumbwa, F.O., Schaubroeck, J. 2009. Leader personality traits and employee voice behavior: Mediating roles of ethical leadership and work group psychological safety. Journal of Applied Psychology, 94(5), 1275-1286.

Wang, M., Yang, T. 2016. Asia Pacific Management Review Investigating the success of knowledge management: An empirical study of small- and medium-sized enterprises, Asia Pacific Manag. Rev., 21(2), 79-91. 